\title{
HOW DOES AN INTEGRATED STEM LIFE SCIENCES UNIT AFFECT MIDDLE SCHOOL STUDENTS' ENGAGEMENT AND SCIENCE CONTENT KNOWLEDGE?
}

\author{
Zeynep Gonca Akdemir, Ph.D. Student, Purdue University, zakdemir@purdue.edu \\ Muhsin Menekse, Assistant Professor, Purdue University, menekse@ purdue.edu \\ Saira Anwar, Assistant Engineer, University of Florida, sairaanwar@ufl.edu \\ S. Selcen Guzey, Associate Professor, Purdue University, sguzey@purdue.edu
}

\begin{abstract}
This study explored the effect of an integrated engineering design-based life sciences unit on middle school students' engagement and science content knowledge, and the role of engagement in predicting their success. Participants were 530 seventh-grade students from rural schools in the Midwest region of the United States. Data included science content pre- and post-assessments and a multidimensional engagement survey. The data were analyzed by conducting paired-sample $t$-tests and multiple regression analysis. Results indicated that students' social engagement increased when they engaged in an integrated engineering design-based life science curriculum unit. Also, students' preassessment scores were found to be the most effective factor for the increase in their science content knowledge.
\end{abstract}

\section{Rationale, Procedure and Findings}

Several research studies in the last decade have shown the positive impact that integrated STEM has on science and mathematics learning when engineering and technology are meaningfully integrated into instruction (e.g., Guzey et al., 2017, Guzey et al., 2016). Thus, this study examined student learning and engagement when seventh-grade teachers taught a unit on cell division (mitosis) through integrated STEM approaches - i.e., integrating challenging engineering design and practices into the life science instruction. During the unit, students learned about the stages of cell division and how an error in mitosis causes cancer. Students used their science knowledge to solve the engineering design challenge in which they created a natural sunscreen that could protect cells from the sun damage that leads to cancer. This unit was aligned with the NGSS Life Science Standards (NGSS Lead States, 2013) about cells and the effects of environmental conditions on the growth of cells.

We collected data on seventh-grade students' $(n=530)$ science content knowledge and their engagement in the entire unit by using pre- and post-assessments. Engagement data included behavioral, emotional, social, and cognitive dimensions. The analysis showed a significant increase in students' science content knowledge and social engagement after teachers implemented the life sciences curriculum unit. Also, emotional engagement, social engagement, and pre-assessment scores were significant predictors of students' post-assessment gains on the cell division content knowledge. Our study results contribute to the prior research that integrated inquiry-based engineering practices into science content and suggest that students' full investment in engineering projects results in better conceptual learning and achievement in science and engineering learning (e.g., Guzey et al., 2017).

\section{References}

Guzey, S. S., Harwell, M., Moreno, M., Peralta, Y., \& Moore, T. (2017). The impact of design-based STEM integration curricula on student achievement in Engineering, Science, and Mathematics. Journal of Science Education \& Technology, 26(2), 207-222. https://doi-org.ezproxy.lib.purdue.edu/10.1007/s 10956-0169673-X

Guzey, S. S., Moore, T. J., Harwell, M., \& Moreno, M. (2016). STEM integration in middle school life science: Student learning and attitudes. Journal of Science Education and Technology, 25(4), 550-560.

NGSS Lead States. (2013). Next generation science standards: For states, by states. Washington, DC: National Academies Press. https://doi.org/10.17226/18290 